\title{
Rates for Vehicle Loans: Race and Loan Source
}

\author{
Kerwin Kofi Charles \\ Harris School \\ University of Chicago \\ 1155 East 60th Street \\ Chicago, IL 60637 \\ Voice: (773) 834-8922 \\ Fax: (773) 702-0926 \\ e-mail: kcharles@gmail.com \\ Erik Hurst \\ Graduate School of Business \\ University of Chicago \\ 5807 South Woodlawn Avenue \\ Chicago, IL 60637 \\ Voice: (773) 834-4073 \\ Fax: (773) 702-0458 \\ e-mail: fehurst@gsb.uchicago.edu \\ Melvin Stephens Jr. \\ H. John Heinz III School of Public Policy and Management \\ Carnegie Mellon University \\ 5000 Forbes Avenue \\ Pittsburgh, PA 15232 \\ Voice: (412) 268-5945 \\ Fax: (412) 268-5339 \\ e-mail: mstep@cmu.edu
}

Session: Assets and Credit Among Low-Income Households

Session Chair: Rebecca Blank

Discussant: Annamaria Lusardi

Corresponding Author: Melvin Stephens Jr. 


\title{
Rates for Vehicle Loans: Race and Loan Source
}

\author{
By Kerwin Kofi Charles, Erik Hurst, and Melvin Stephens Jr. *
}

A household's vehicle purchases are among its largest expenditure outlays. Moreover, unlike housing purchases, which a typical household may make once or twice over a lifetime, a household may well buy several cars over the same interval. The magnitude and relative frequency of vehicle purchases suggest that differential treatment by race in the vehicle market may have important implications for differences in wealth and financial wellbeing by race. Yet, whereas a robust literature in economics has studied virtually all aspects of racial treatment in the housing market, corresponding work about vehicles has been relatively sparse, with most work focusing on racial differences in prices paid (Pinelopi Goldberg (1996) and Fiona Scott-Morton, Florian Zettelmeyer, and Jorge Silva-Risso (2003)). Very little previous attention has been paid to whether there is differential racial treatment in another important outcome in the vehicle market: the interest rates that households pay on the loans used to purchase vehicles. ${ }^{1}$

Calculations using data from the Survey of Consumer Finances indicate that loans for vehicle purchases are primarily obtained from one of two sources. Roughly two-thirds of vehicle loans originate from the traditional banking sector: commercial banks, savings institutions, or credit unions. Vehicle manufacturers finance the remaining one-third of auto loans through their financing arms; the Ford Motor Credit Company (FMCC), and General Motors Acceptance Corporation (GMAC) are two examples of these kinds of institutions.

\footnotetext{
* Charles: Harris School, University of Chicago, 1155 East 60th Street, Chicago, IL 60637 (e-mail: kcharles@gmail.com); Hurst: Graduate School of Business, University of Chicago, 5807 South Woodlawn Avenue, Chicago, IL 60637 (e-mail: fehurst@gsb.uchicago.edu); Stephens: H. John Heinz III School of Public Policy and Management, Carnegie Mellon University, 5000 Forbes Avenue, Pittsburgh, PA 15232 (e-mail: mstep@cmu.edu). We would like to thank Mark Aguiar, Raphael Bostic, Steve Davis, Austan Goolsbee, Gita Gopinath, Arthur Kennickell, and Anna Lusardi for helpful comments. Hurst would also like to acknowledge financial support from the University of Chicago's Graduate School of Business.

${ }^{1}$ The analysis by Mark Cohen (2007) is an important exception. However, our analysis differs from and extends his work in various ways. Whereas Cohen only examines loans using data from vehicle financing companies, we are able to study loans from all originating institutions. In addition, since the industry data he uses does not contain race identifiers, Cohen matches loans to state driver's license data containing race information, which is only available for a subset of states. We use selfreported race data from a nationally representative household survey.
} 
Several recent lawsuits have alleged, and various press accounts speculated, that there may be differential treatment by race in interest rates paid at vehicle finance companies. ${ }^{2}$ In his analysis of data from these financing companies obtained as part of the lawsuits, Cohen (2007) finds that roughly 43 to 72 percent of Blacks are charged interest rate "markups" while only 22 to 47 percent of Whites face these higher prices for vehicle financing.

It is hard to conclude from the evidence obtained by analyzing the vehicle financing company data, however, that there is indeed differential racial treatment throughout the market. Differential treatment in a given part of the market need not imply that Blacks pay different rates in equilibrium, particularly in the absence of information on Blacks' differential propensity to use one type of institution over another for loans, and about any differential treatment they may receive in other parts of the vehicle financing market. These considerations imply that in order to understand equilibrium, market-level differential treatment one would ideally need information about consumer characteristics, details about the vehicles purchased, and information about the features and sources of their vehicle loans. The Survey of Consumer Finances data set has all of these features and is thus well suited to studying this question.

\section{Data and Sample Description}

We use data from the 1992, 1995, 1998, and 2001 waves of the Survey of Consumer Finances (SCF). Importantly, the SCF is a household survey which provides information on household demographics, including information on household financial position and credit history. The survey also contains detailed information on vehicle purchases, including the specific type of vehicle purchased, the amount and terms of the vehicle loan, and where the loan was originated.

\footnotetext{
${ }^{2}$ A number of vehicle financing companies recently faced class actions lawsuits alleging that they charged higher interest rate markups to Black and Hispanic borrowers including those owned by Chrysler, Ford, General Motors, Honda, Nissan, and Toyota. Some of these lawsuits, such those filed against General Motors and Nissan, were settled out of court with no monetary damages.
} 
We study vehicle purchases made by SCF households in the three years preceding the survey. $^{3}$ Only households that took out a loan to finance the vehicle purchase are studied, and we exclude the handful of households that report not making monthly loan payments. We drop cases where the head's race is neither White nor Black and where there is missing data for any of the control variables described below. In addition, we only use the most recent vehicle purchase for households with more than one such purchase during the three year window. We use the SCF core sampling weights in the analysis that follows. In total, our vehicle loan sample contains 3,045 households, $10.5 \%$ of which were Black.

[Table 1 about here]

Panel A of Table 1 reports average loan features in the loan sample. There is no statistically significant racial difference in original loan amounts or the length of the loan. However, the loans to Black and White vehicle purchases differ on every other dimension. In particular, Blacks are less likely than Whites to have purchased a new vehicle, and are dramatically more likely to have obtained a vehicle finance company loan. The Table also indicates that the interest rates paid by Blacks are on average a full 100 basis points higher: $10.6 \%$ versus $9.6 \%$. Consistent with the similarities in loan amount and length and different interest rates, Blacks have higher monthly vehicle loan payments.

How different are the households purchasing vehicles by race? Panel B of Table 1 shows that while there is no difference in the household head's age, Black vehicle purchasers are much less likely to be in male-headed households and have much lower household incomes. In addition, Black and White households differ significantly in terms of their credit-worthiness -- at

\footnotetext{
${ }^{3}$ For example, for those households in the 2001 survey, we include in our sample anyone who purchased a car during the 1998 , 1999, 2000 or 2001 surveys.
} 
least as measured by factors available in the SCF which are likely very highly correlated with the credit scores that lenders observe. For example, Panel $\mathrm{C}$ of the Table shows that Blacks are much more likely to have recently been turned down for a loan of some sort; to have been late by more by two months in paying a bill; and to have ever declared bankruptcy. Similar differences exist in the likelihood of owning a home, and the likelihood of having revolving credit card debt.

[Figure 1 about here]

Given that Blacks are much more likely than Whites to obtain loans from finance companies, we next examine the interest rate differences across different types of lending institutions. Panel A of the Figure 1 shows that the mean racial difference in rates comes from a rightward shift in the overall distribution of rates for Blacks relative to Whites. Blacks are more likely to pay very high rates while Whites are more likely to pay rates in the middle of distribution. Panel B shows the distribution of interest rates for Blacks and Whites for loans from traditional banks and credit unions. Strikingly, we find that while there remains a mean racial difference in rates paid, there does not appear to be a difference in tails of the distribution. This is quite different from what is true for loans from vehicle finance companies - the distributions for which are presented in Panel C. This Panel shows that for these loans, racial differences are pronounced in the two tails of the distribution. Thus, Blacks are much more likely than Whites to pay very high interest rates, and much less likely to pay rates that are very low. On the whole the figure indicates that the racial distribution of rates is quite different by institution type, and that these differences vary at different points in the distributions.

\section{Regression Analysis}


We implement a simple difference-in-differences framework to formally assess the role of financial institutions. Specifically, we estimate a series of regressions of the form

$$
\text { Rate }_{i}=\beta_{0}+\beta_{1} \text { Black }_{i}+\beta_{2} \text { Finance } \beta_{3}\left(\text { Black }_{i}^{*} \text { Finance }\right)+\gamma V_{i}+\delta X_{i}+\varepsilon_{i}
$$

In (1), Rate is the interest rate paid, the vector $V_{i}$ is a set of loan characteristics which includes the amount and the length of the loan, an indicator for a new vehicle loan, and calendar year of purchase indicators, and the vector $X_{i}$ contains the household demographic and financial measures found in the second and third panels of Table 1. The variables Black $k_{i}$ and Finance $_{i}$ denote, respectively, that a household is Black and that the vehicle loan was obtained from a vehicle financing company. In this framework the coefficient $\beta_{1}$ measures the racial interest rate differential while $\beta_{2}$ measures the average difference in rates paid to finance companies as compared to traditional banking institutions which include banks, savings institutions, and credit unions. We refer collectively to these traditional banking institutions simply as "banks" below. The coefficient on the interaction term $\beta_{3}$ measures the difference between how Blacks are treated at finance companies versus traditional banking institutions compared to the difference in the treatment of Whites across the two kinds of institutions.

The results shown in Figure 1 suggest many of the most interesting differences may exist at particular percentile points in the distribution. In addition, Cohen's (2001, 2003, 2004a, 2004b) analysis of industry data indicates that markups are paid by half of Blacks and less than one-third of Whites. We therefore estimate (1) quantile regressions at the median and the $25^{\text {th }}$ and $75^{\text {th }}$ percentiles.

[Table 2 about here] 
Table 2 presents the regression results. All of the estimates in the table are from regressions which control for household demographics and indicators of financial position. The first panel presents the estimated results at the $25^{\text {th }}$ percentile. The first column shows that there is no statistically significant racial difference in rates at the $25^{\text {th }}$ percentile. The second column adds a control for whether the loan was obtained at a vehicle finance company. The significant point estimate of -0.38 implies that at the $25^{\text {th }}$ percentile vehicle finance companies charge lower rates than do banks. The fact that Blacks are more likely to use finance companies means that the estimated racial gap at the $25^{\text {th }}$ percentile is now positive when controlling for the loan source, although the effect is not statistically significant.

The coefficient on the interaction term in the third column measures the relative difference between the rates that Blacks pay by using finance companies rather than banks, compared to the difference in rates that Whites pay by using finance companies rather than banks. The results indicate that although finance companies overall charge lower rates than banks at the $25^{\text {th }}$ percentile, the gain to Blacks from using finance companies rather than banks is smaller than the gain to Whites. The coefficient on the Black main effect in this difference-indifferences specification measures the racial interest rate differential at banks, and the results show that this effect is not statistically significant. In summary, there is very little difference in interest rates paid, by race, at the $25^{\text {th }}$ percentile. Finance companies charge slightly lower rates than banks at this part of the distribution, although the gain to Blacks is smaller than that for Whites. Finally, there is no racial difference in the rates charged by banks at the $25^{\text {th }}$ percentile.

The first column in the second panel shows that, as was true at the $25^{\text {th }}$ percentile, there is no racial difference in rates paid at the median after controlling for observables. Unlike the $25^{\text {th }}$ percentile, at the median we find that finance companies charge higher rates overall than do 
banks. This positive point estimate on the interaction term in the third column implies that this premium is larger for Blacks although the effect is not statistically significant.

The results for the $75^{\text {th }}$ percentile presented in the last panel are strikingly different from the other two sets of regressions. First, note that there is a very large 134 basis point racial difference in rates paid at the $75^{\text {th }}$ percentile. This is in stark contrast to the results for lower quantiles, where Blacks and Whites are found to pay the same rates, after accounting for observable characteristics. The estimates in the second column indicate that finance companies charge almost 160 basis points more at the $75^{\text {th }}$ percentile as compared to banks. Interestingly, controlling for the source of the loan does not appreciably lower the overall race gap: Blacks at the $75^{\text {th }}$ percentile pay rates 120 basis points higher than those paid by Whites, after accounting for the difference in where the loan was obtained. The difference-in-differences estimates in the third column show that whereas finance companies charge higher rates overall at the $75^{\text {th }}$ percentile, this premium over traditional bank rates is especially large for Blacks, for whom the finance company premium is 168 basis points higher than the large premia paid by Whites for using these institutions. These effects are not only large but are also strongly statistically significant. As we find throughout the distribution, the rates Blacks pay at traditional banks are not statistically different from those paid by Whites.

\section{Discussion}

Using data from the SCF, our results indicate that after accounting for observable demographic and financial well being measures, most of the racial difference in interest rates in the vehicle purchase market occurs at the percentiles above the median. In addition, differences in rates at these higher percentiles derive from two sources. The first source is the greater propensity of Blacks to use finance companies for their loans - a behavior which leads to higher 
interest payments because finance companies charge all consumers above the median higher rates. ${ }^{4}$ The second source is that racial minorities receive differential treatment from finance companies. That is, Blacks appear to pay higher premiums to use these institutions than do Whites. On the whole, we find no evidence of difference racial treatment in rates paid at traditional banking institutions at any point in the distribution. That we find no evidence of interest rate differences by race below the median suggests that for persons whose credit and other characteristics enable them to quality for very low rates, differential racial treatment is not a concern. This finding is consistent with those of Cohen's examination of the vehicle loan finance industry.

The results raise a number of questions. Chief among these is the puzzle of why Blacks finance their loans at vehicle finance companies at all, given that they pay higher rates of interest there? Might racial differences in financial literacy such as those documented by Annamaria Lusardi and Olivia S. Mitchell (2006) explain this behavior? Or, do Blacks face a differential probability of rejection at the lower interest rate traditional banks and credit unions? Our results are indicative of a sharp difference between the vehicle and housing markets. In the latter case, it appears that any differential treatment operates on the dimension of access to credit rather than the specific terms of the loan (Charles and Hurst (2002)). Why these two markets seem to operate differently is another open question.

\footnotetext{
${ }^{4}$ In results not shown here, the higher likelihood of Blacks to use these companies is not affected when controlling for the same set of regressors as those used in Table 2.
} 


\section{References}

Charles, Kerwin K. and Erik Hurst (2002). “The Transition to Home Ownership and the BlackWhite Wealth Gap,” Review of Economics and Statistics, May, 84(2), pg 281-297.

Cohen, Mark (2007). “Imperfect Competition in Auto Lending: Subjective Markup, Racial Disparity, and Class Action Litigation,” Vanderbilt Law School Law and Economics Research Paper No. 07-01.

Goldberg, Pinelopi (1996). "Price Discrimination in New Car Purchases: Evidence from the Consumer Expenditure Survey,” Journal of Political Economy, Vol. 104, No. 3 (June 1996), pp. 622-654.

Lusardi, Annamaria and Olivia S. Mitchell (2006). "Financial Literacy and Planning: Implications for Retirement Wellbeing,” Pension Research Council Working Paper 200601.

Scott-Morton, Fiona, Florian Zettelmeyer and Jorge Silva-Risso (2003). “Consumer Information and Price Discrimination: Does the Internet Affect the Pricing of New Cars to Women and Minorities?” Quantitative Marketing and Economics:1:1:65-92. 
Table 1: Vehicle Loan, Demographic, and Financial Characteristics by Race

\begin{tabular}{|c|c|c|c|c|c|}
\hline Variable & $\begin{array}{c}\text { I } \\
\text { All } \\
\text { Hholds }\end{array}$ & $\begin{array}{c}\text { II } \\
\text { White } \\
\text { Hholds }\end{array}$ & $\begin{array}{c}\text { III } \\
\text { Black } \\
\text { Hholds } \\
\end{array}$ & Difference & $\begin{array}{c}\mathrm{V} \\
\text { p-value of } \\
\text { Difference }\end{array}$ \\
\hline \multicolumn{6}{|l|}{ A. Vehicle Loan Characteristics } \\
\hline Interest Rate & 9.69 & 9.57 & 10.60 & 1.03 & $<0.01$ \\
\hline Monthly Payment & 369 & 366 & 389 & 23 & 0.01 \\
\hline Loan Length (Months) & 50.4 & 50.5 & 49.5 & -1.0 & 0.18 \\
\hline Original Loan Amount & 15,310 & 15,240 & 15,860 & 630 & 0.18 \\
\hline New Vehicle & 0.52 & 0.53 & 0.46 & -0.06 & 0.04 \\
\hline Finance Company Loan & 0.36 & 0.34 & 0.51 & 0.17 & $<0.01$ \\
\hline \multicolumn{6}{|l|}{ B. Demographic Characteristics } \\
\hline Male & 0.82 & 0.84 & 0.64 & -0.21 & $<0.01$ \\
\hline Age & 42.6 & 42.7 & 41.8 & -0.9 & 0.30 \\
\hline Household Income & 82,700 & 85,410 & 62,630 & $-22,770$ & $<0.01$ \\
\hline \multicolumn{6}{|l|}{ C. Financial Measures } \\
\hline $\begin{array}{l}\text { Turned Down For Loan } \\
\text { In Past Five Years }\end{array}$ & 0.26 & 0.24 & 0.39 & 0.14 & $<0.01$ \\
\hline $\begin{array}{l}\text { Turned Down For Car Loan } \\
\text { In Past Five Years }\end{array}$ & 0.08 & 0.08 & 0.09 & 0.00 & 0.88 \\
\hline Ever Late Paying Bills & 0.17 & 0.15 & 0.29 & 0.13 & $<0.01$ \\
\hline $\begin{array}{l}\text { Ever Late More Than Two Months } \\
\text { When Paying A Bill }\end{array}$ & 0.07 & 0.06 & 0.12 & 0.05 & 0.01 \\
\hline Ever Bankrupt & 0.07 & 0.07 & 0.11 & 0.05 & 0.02 \\
\hline Has A Savings Account & 0.60 & 0.60 & 0.57 & -0.03 & 0.33 \\
\hline Has A Checking Account & 0.91 & 0.92 & 0.83 & -0.08 & $<0.01$ \\
\hline Own A Home & 0.58 & 0.60 & 0.45 & -0.15 & $<0.01$ \\
\hline Holds Revolving Credit Card Debt & 0.66 & 0.66 & 0.70 & 0.04 & 0.15 \\
\hline $\mathrm{N}$ & 3,045 & 2,725 & 320 & & \\
\hline
\end{tabular}


Table 2: Estimated Racial Differences in Vehicle Loan Rates

\begin{tabular}{|c|c|c|c|c|c|c|c|c|c|}
\hline \multirow[b]{2}{*}{ Regressors } & \multicolumn{3}{|c|}{ 25th Percentile } & \multicolumn{3}{|c|}{ Median } & \multicolumn{3}{|c|}{ 75th Percentile } \\
\hline & I & II & III & I & II & III & I & II & III \\
\hline Black & $\begin{array}{c}-0.09 \\
(0.17) \\
{[0.605]}\end{array}$ & $\begin{array}{c}0.03 \\
(0.17) \\
{[0.871]}\end{array}$ & $\begin{array}{c}-0.13 \\
(0.22) \\
{[0.539]}\end{array}$ & $\begin{array}{c}0.11 \\
(0.16) \\
{[0.492]}\end{array}$ & $\begin{array}{c}0.02 \\
(0.16) \\
{[0.909]}\end{array}$ & $\begin{array}{c}-0.05 \\
(0.22) \\
{[0.821]}\end{array}$ & $\begin{array}{c}1.34 \\
(0.28) \\
{[0.000]}\end{array}$ & $\begin{array}{c}1.26 \\
(0.19) \\
{[0.000]}\end{array}$ & $\begin{array}{c}0.34 \\
(0.31) \\
{[0.268]}\end{array}$ \\
\hline $\begin{array}{l}\text { Finance Company } \\
\text { Loan }\end{array}$ & & $\begin{array}{c}-0.38 \\
(0.11) \\
{[0.001]}\end{array}$ & $\begin{array}{c}-0.41 \\
(0.11) \\
{[0.000]}\end{array}$ & & $\begin{array}{c}0.67 \\
(0.11) \\
{[0.000]}\end{array}$ & $\begin{array}{c}0.57 \\
(0.11) \\
{[0.000]}\end{array}$ & & $\begin{array}{c}1.60 \\
(0.13) \\
{[0.000]}\end{array}$ & $\begin{array}{c}1.41 \\
(0.16) \\
{[0.000]}\end{array}$ \\
\hline $\begin{array}{l}\text { Black } \\
\text { *Finance Company Loan }\end{array}$ & & & $\begin{array}{c}0.26 \\
(0.30) \\
{[0.384]}\end{array}$ & & & $\begin{array}{c}0.33 \\
(0.31) \\
{[0.292]}\end{array}$ & & & $\begin{array}{c}1.68 \\
(0.43) \\
{[0.000]}\end{array}$ \\
\hline
\end{tabular}

Notes: This Table contains estimates of equation (1) described in the text. All regressions in this Table include demographic and financial controls. The demographic controls include a gender of the household head indicator, age of the household head and its squared, annual household income and its square. Financial controls include the seven measures discussed in the text. Standard errors are in parentheses and p-values are in brackets. 
Figure 1: Vehicle Loan Rates Across Lending Institutions by Race

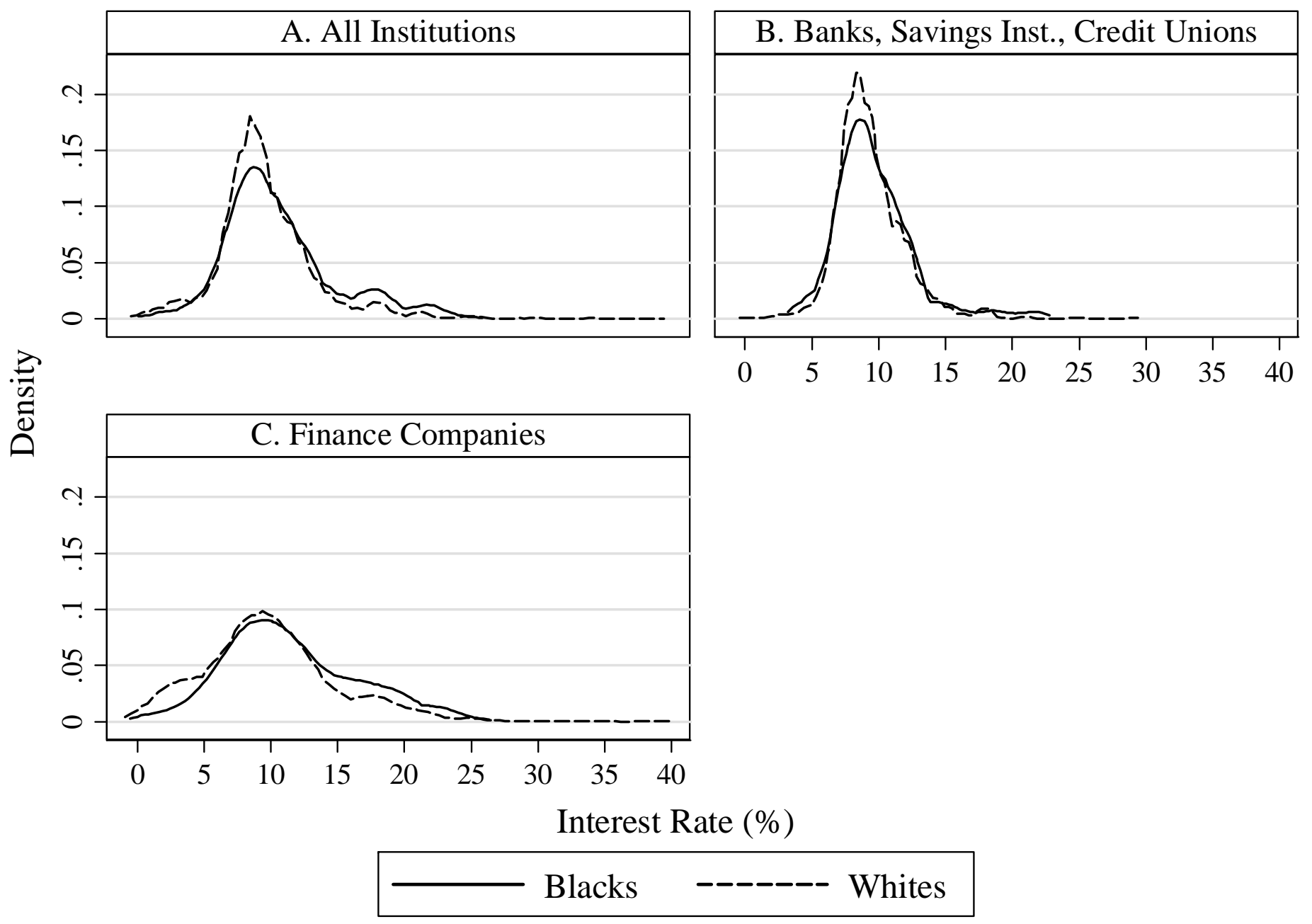

